\title{
Temperature Controls Crystalline Iron Oxide Utilization by Microbial Communities in Methanic Ferruginous Marine Sediment Incubations
}

David A. Aromokeye1,2,3, Tim Richter-Heitmann1, Oluwatobi E. Oni1,2, Ajinkya Kulkarni1,2,3, Xiuran Yin 1,2,3, Sabine Kasten ${ }^{2,4,5}$ and Michael W. Friedrich ${ }^{1,2 *}$

${ }^{1}$ Microbial Ecophysiology Group, Faculty of Biology/Chemistry, University of Bremen, Bremen, Germany, ${ }^{2}$ MARUM, Center for Marine Environmental Sciences, University of Bremen, Bremen, Germany, ${ }^{3}$ International Max Planck Research School for Marine Microbiology, Max-Planck-Institute for Marine Microbiology, Bremen, Germany, ${ }^{4}$ Alfred Wegener Institute Helmholtz Centre for Polar and Marine Research, Bremerhaven, Germany, ${ }^{5}$ Faculty of Geosciences, University of Bremen, Bremen, Germany

OPEN ACCESS

Edited by:

Mark Alexander Lever,

ETHZürich, Switzerland

Reviewed by:

Michael Pester,

Deutsche Sammlung von

Mikroorganismen und Zellkulturen

(DSMZ), Germany

John Senko,

University of Akron, United States

*Correspondence:

Michael W. Friedrich

michael.friedrich@uni-bremen.de

Specialty section: This article was submitted to Extreme Microbiology, a section of the journal

Frontiers in Microbiology

Received: 10 August 2018 Accepted: 09 October 2018 Published: 30 October 2018

Citation:

Aromokeye DA

Richter-Heitmann T, Oni OE, Kulkarni A, Yin X, Kasten S and Friedrich MW (2018) Temperature

Controls Crystalline Iron Oxide Utilization by Microbial Communities in Methanic Ferruginous Marine

Sediment Incubations.

Front. Microbiol. 9:2574. doi: 10.3389/fmicb.2018.02574
Microorganisms can use crystalline iron minerals for iron reduction linked to organic matter degradation or as conduits for direct interspecies electron transfer (mDIET) to syntrophic partners, e.g., methanogens. The environmental conditions that lead either to reduction or conduit use are so far unknown. We investigated microbial community shifts and interactions with crystalline iron minerals (hematite and magnetite) in methanic ferruginous marine sediment incubations during organic matter (glucose) degradation at varying temperatures. Iron reduction rates increased with decreasing temperature from $30^{\circ} \mathrm{C}$ to $4^{\circ} \mathrm{C}$. Both hematite and magnetite facilitated iron reduction at $4^{\circ} \mathrm{C}$, demonstrating that microorganisms in the methanic zone of marine sediments can reduce crystalline iron oxides under psychrophilic conditions. Methanogenesis occurred, however, at higher rates with increasing temperature. At $30^{\circ} \mathrm{C}$, both hematite and magnetite accelerated methanogenesis onset and maximum process rates. At lower temperatures $\left(10^{\circ} \mathrm{C}\right.$ and $\left.4^{\circ} \mathrm{C}\right)$, hematite could still facilitate methanogenesis but magnetite served more as an electron acceptor for iron reduction than as a conduit. Different temperatures selected for different key microorganisms: at $30^{\circ} \mathrm{C}$, members of genus Orenia, Halobacteroidaceae, at $10^{\circ} \mathrm{C}$, Photobacterium and the order Clostridiales, and at $4^{\circ} \mathrm{C}$ Photobacterium and Psychromonas were enriched. Members of the order Desulfuromonadales harboring known dissimilatory iron reducers were also enriched at all temperatures. Our results show that crystalline iron oxides predominant in some natural environments can facilitate electron transfer between microbial communities at psychrophilic temperatures. Furthermore, temperature has a critical role in determining the pathway of crystalline iron oxide utilization in marine sediment shifting from conduction at $30^{\circ} \mathrm{C}$ to predominantly iron reduction at lower temperatures.

Keywords: DIET, temperature control, marine sediment, iron reduction, methanogenesis, microbial community analysis 


\section{INTRODUCTION}

Iron oxide minerals are ubiquitous in natural environments (Straub et al., 2001; Kappler and Straub, 2005; Braunschweig et al., 2013) and exist chemically as amorphous, poorly crystalline or crystalline phases (Cornell and Schwertmann, 2003). Microbial reduction of amorphous and poorly crystalline iron oxide phases is thermodynamically more favorable than using crystalline phases (Weber et al., 2006); therefore, microorganisms preferentially utilize less crystalline phases for dissimilatory and fermentation-linked iron reduction (Munch and Ottow, 1980; Munch and Ottow, 1983; Lovley and Phillips, 1986, 1987; Lovley, 1991). There is growing evidence that the more crystalline iron oxide mineral phases may nevertheless support microbial metabolism either as (I) terminal electron acceptors during oxidation of complex organic matter or fermentation end products such as acetate and $\mathrm{H}_{2}$ (Lentini et al., 2012; Hori et al., 2015) or as (II) conduits for electron transfer between microorganisms living in syntrophic association (Kato et al., 2012; Liu et al., 2015).

Several incubation studies with marine sediments have previously demonstrated the feasibility of microbial reduction of amorphous iron(III) and poorly crystalline phases like ferrihydrite under psychrophilic (Zhang et al., 1999; Stapleton et al., 2005; Roh et al., 2006; Vandieken et al., 2006), mesophilic (Roden and Lovley, 1993) and thermophilic conditions (Kashefi and Lovley, 2003; Kashefi et al., 2008; Manzella et al., 2013). Microbial reduction of crystalline iron oxides such as goethite $(\alpha-\mathrm{FeOOH})$, hematite $\left(\alpha-\mathrm{Fe}_{2} \mathrm{O}_{3}\right)$ and magnetite $\left[\mathrm{Fe}(\mathrm{II}) \mathrm{Fe}(\mathrm{III})_{2} \mathrm{O}_{4}\right]$ was previously demonstrated under mesophilic (Roden and Zachara, 1996; Lentini et al., 2012; Hori et al., 2015) but not under psychrophilic conditions. Meanwhile, elevated concentrations of dissolved $\mathrm{Fe}^{2+}$ have been detected in the methanic zone of some sub-seafloor sediments bearing appreciable amounts of these crystalline mineral phases (e.g., Hensen et al., 2003; Riedinger et al., 2005; März et al., 2008; Riedinger et al., 2014; Oni et al., 2015a; Egger et al., 2017). Therefore, microbial reduction of crystalline iron oxides could be a prime metabolic process in these sediment layers. Despite the large body of work on iron reduction at varying temperature conditions and in various environments, knowledge of the diversity of microorganisms involved in crystalline iron mineral reduction in cold marine sediments is still limited.

Mineral-mediated electron transfer between metabolically dependent microbes is particularly important in methanogenic environments such as flooded rice field soils (Kato et al., 2012; Zhou et al., 2014). Despite mineral-meditated direct interspecies electron transfer (mDIET) being central to the functioning of methane-producing microbial communities, the environmental factors that govern these interactions are yet to be studied (Shrestha and Rotaru, 2014). In contrast to other environments such as rice field soils (Kato et al., 2012; Zhou et al., 2014; Li et al., 2015; Zhuang et al., 2015) freshwater (Jiang et al., 2013; Zhang and Lu, 2016) and coastal sediments (Rotaru et al., 2018), microbial communities capable of mDIET in methanic marine sediments are not known.
Although it is established that microorganisms from different environments can reduce crystalline iron minerals or utilize them as conduits to facilitate electron transfer to syntrophic partners, controls of these interactions under different environmental conditions are not known yet. Here, we posit that temperature controls the mode of crystalline iron minerals utilization, either reduction, conduction or both. To address this hypothesis, we specifically studied (1) the role of crystalline iron minerals during microbial community shifts in marine sediment incubations under varying temperature conditions, (2) the potential for reduction of crystalline iron minerals in sub-seafloor sediments at different temperatures and (3) identified microbial populations that can interact with crystalline iron minerals in marine sediments under varying temperature regimes.

\section{MATERIALS AND METHODS}

\section{Sampling Site}

The Helgoland Mud Area is a highly depositional site of finegrained mud located in the German Bight, North Sea. The depositional history and geochemical profiles of this site were previously described (Hebbeln et al., 2003; Oni et al., 2015a). Samples were collected using a gravity corer (5 m core length) during RV HEINCKE research expedition HE $443\left(54^{\circ} 05.23^{\prime} \mathrm{N}\right.$; $007^{\circ} 58.04^{\prime} \mathrm{E}$ ) in May 2015. The core HE443/077-1 was stored at $4^{\circ} \mathrm{C}$ on board, transported to the laboratory within a few days of core retrieval, and sliced into $25-\mathrm{cm}$ sections. Each $25-\mathrm{cm}$ section was stored at $4^{\circ} \mathrm{C}$ in $2.6-\mathrm{L}$ jars, under a headspace of $\mathrm{N}_{2}(99.999 \%$ purity, Linde, Germany).

\section{Incubation Experiments}

Anoxic 50-ml slurry incubations were prepared in $120-\mathrm{ml}$ serum vials with sediment from 416 to 441 and 441 to $466 \mathrm{~cm}$ depths and anoxic sulfate-free artificial sea water (ASW; composition [L $\mathrm{L}^{-1}$ ]: $26.4 \mathrm{~g} \mathrm{NaCl}, 11.2 \mathrm{~g} \mathrm{MgCl}_{2} \cdot 6 \mathrm{H}_{2} \mathrm{O}, 1.5 \mathrm{~g}$ $\mathrm{CaCl}_{2} \cdot 2 \mathrm{H}_{2} \mathrm{O}$ and $\left.0.7 \mathrm{~g} \mathrm{KCl}\right)$ at a ratio of $1: 3(\mathrm{w} / \mathrm{v})$ under a headspace of $\mathrm{N}_{2}$. Incubations $(n=9)$ were supplemented by adding $\sim 1,020 \mu$ moles of iron oxides (hematite or magnetite; LanXess, Germany) and $68 \mu$ moles of glucose as electron donor. Control incubations ("glucose only," $n=9$ ) were supplemented with $68 \mu$ moles glucose only (Supplementary Table S1). Control sediment slurry incubations containing iron oxides only were considered not necessary as previous incubation studies with subsurface sediments from the Helgoland mud area demonstrated that endogenous organic matter is not reactive enough to stimulate iron reduction and methanogenesis within tolerable laboratory incubation times ( $~ 200$ days; Oni, 2015). The sediments of the Helgoland Mud Area are rich in different phases of iron minerals (up to $0.8 \mathrm{wt} \%$; Oni et al., 2015a). Hence, adding a carbon source (glucose) to the sediment even without adding iron oxides stimulated microbial iron reduction in the sediments. The potential for reduction of amended hematite (HG) or magnetite (MG) was evaluated by comparing the amount of $\mathrm{Fe}^{2+}$ formed in crystalline iron-treated incubations to those of the "glucose 
only" control (G). Triplicates of each treatment set were incubated statically in the dark at $4^{\circ} \mathrm{C}, 10^{\circ} \mathrm{C}$, or $30^{\circ} \mathrm{C}$. Triplicate supplementary incubations were set up at $30^{\circ} \mathrm{C}$, for testing the effect of the inhibitor 2-bromoethanesulfonate (BES) on methanogenesis and iron reduction in the presence of crystalline iron oxides. This was achieved by adding $\sim 15 \mathrm{mM}$ BES to freshly prepared triplicate slurries ("glucose only," magnetite and glucose, hematite and glucose). Another set-up in duplicates was done for all treatments across all temperatures to investigate the effects of $\mathrm{pH}$ during glucose fermentation (Supplementary Table S2).

\section{Analytical Methods}

All incubations were first sampled after approximately $12 \mathrm{~h}$ at respective temperatures, and designated as "day 0." One milliliter of slurry was collected under anoxic conditions in $1.5 \mathrm{ml}$ reaction tubes pre-flushed with $\mathrm{N}_{2}$. $\mathrm{HCl}$ extractable $\mathrm{Fe}$ (II) was determined for each sample first by mixing $100 \mu \mathrm{l}$ of slurry from each sample with $100 \mu \mathrm{l} 0.5 \mathrm{M} \mathrm{HCl}$. The mixture was subsequently incubated at room temperature for $24 \mathrm{~h}$. Afterward, the supernatant was collected by centrifugation $(15,300 \times g$, $5 \mathrm{~min}$ ) followed by spectrophotometric determination of $\mathrm{Fe}(\mathrm{II})$. However, we observed high amounts of $\mathrm{HCl}$ extractable $\mathrm{Fe}(\mathrm{II})$ at day 0 that likely originated from precipitated iron carbonate (e.g., siderite) and sulfur compounds (e.g., FeS) within sediment samples. Given the large background of sediment indigenous $\mathrm{Fe}(\mathrm{II})$ compounds, it was not possible to determine accurately the amount of freshly formed Fe(II) over the course of the incubation, which precipitates rather rapidly (Supplementary Figure S1). Therefore, the aqueous $\mathrm{Fe}^{2+}$ measured was used as a proxy for evaluating iron reduction kinetics. This was done by centrifugation of freshly collected anoxic slurry and directly adding $100 \mu \mathrm{l}$ of supernatant from each centrifuged sample $(15,300 \times g, 5 \mathrm{~min})$ to ferrozine reagent following Viollier et al. (2000). The rest of the slurry was stored at $-20^{\circ} \mathrm{C}$ and subsequently used for DNA extraction where required.

Methane concentrations in incubation headspace samples $(100 \mu \mathrm{l})$ were monitored over time using a gas chromatograph (GC) (Shimadzu GC-2014, Tokyo, Japan) coupled to a methanizer (nickel reactor, CP 11952, Agilent, Germany). GC was equipped with a flame ionization detector and a packed column (Porapak Q, $2 \mathrm{~m} \times 1 / 8^{\prime \prime}$; inner diameter $2 \mathrm{~mm}$, mesh range: 80/100; Agilent, Waldbronn, Germany). $\mathrm{H}_{2}$ served both as carrier gas (99.999\% purity; $500 \mathrm{kPa}, 30 \mathrm{ml} \mathrm{min}^{-1}$ flow rate) and combustion gas (40 $\mathrm{kPa})$. Compressed air $(50 \mathrm{kPa})$ was used for combustion, while make-up gas was $\mathrm{N}_{2}(500 \mathrm{kPa})$. Temperature conditions were as follows; detector $\left(200^{\circ} \mathrm{C}\right)$, injector $\left(120^{\circ} \mathrm{C}\right)$, column $\left(70^{\circ} \mathrm{C}\right)$, and methanizer $\left(350^{\circ} \mathrm{C}\right)$. Chromatographic data was recorded using a Peak Simple data system (model 2002, SRI, Bad Honnef, Germany). Methane amounts formed in headspace were calculated using the ideal gas law with incubation temperature as variable. Methanogenesis rates were systematically evaluated for each time-point by dividing the methane concentration change by the time elapsed between two successive time-points measured per replicate $\left(\Delta\left[\mathrm{CH}_{4}\right]^{*} \Delta \mathrm{t}^{-1}\right)$.

\section{Nucleic Acid Extraction}

One milliliter of slurry from individual incubations, at specific time points, was used for nucleic acid extraction following a modified protocol from Lueders et al. (2004). Nucleic acids were precipitated from aqueous supernatant by adding two volumes of $30 \%$ polyethylene glycol (PEG-6000) followed by centrifugation $\left(15,300 \times g, 90 \mathrm{~min}\right.$ at $\left.4^{\circ} \mathrm{C}\right)$. Pellets were washed twice with $500 \mu \mathrm{l} 70 \%$ ethanol $\left(15,300 \times g, 5 \mathrm{~min}\right.$ at $\left.4^{\circ} \mathrm{C}\right)$ followed by elution in $50 \mu \mathrm{l}$ diethylpyrocarbonate (DEPC) treated water (Carl Roth, Germany). Nucleic acid concentrations were measured with NanoDrop 1000 spectrophotometer (Peqlab Biotechnologie, Erlangen, Germany). For further processing, day 0 samples from the "glucose only" incubations were taken as day 0 for all incubations. All extracted nucleic acids were stored at $-20^{\circ} \mathrm{C}$ until use.

\section{Amplification of 16S rRNA Genes and Illumina Hiseq Sequencing}

Illumina amplicon sequencing PCR was prepared using primers targeting 16S rRNA genes of either Bacteria or Archaea. Bacteria targeting primers used were Bac515F (5'GTGYCAGCMGCCGCGGTAA-3'; Parada et al., 2016) and Bac805R (5'-GACTACHVGGGTATCTAATCC-3'; Herlemann et al., 2011). Archaea targeting primers were Arc519F (5'CAGCMGCCGCGGTAA-3'; Ovreås et al., 1997) and Arc806R (GGACTACVSGGGTATCTAAT; Takai and Horikoshi, 2000). Each primer had in addition a unique barcode sequences $(8 \mathrm{bp}$; Hamady et al., 2008) that facilitated multiplexing of several samples in one sequence library.

PCR reaction mix $(50 \mu \mathrm{l})$ contained $1 \times$ KAPA HiFi buffer, $0.3 \mathrm{mM}$ dNTP mix, $0.25 \mathrm{U}$ KAPA HiFi DNA polymerase (KAPA Biosystems, Germany), $1.5 \mu \mathrm{M}$ each of forward and reverse primer pairs, and $2 \mu \mathrm{l}$ of 10x diluted DNA template from each sample. Thermal cycling conditions include initial denaturation at $95^{\circ} \mathrm{C}$ for $5 \mathrm{~min}$, final denaturation at $98^{\circ} \mathrm{C}$ for $20 \mathrm{~s}, 20 \mathrm{~s}$ of annealing at $60^{\circ} \mathrm{C}$, extension at $72^{\circ} \mathrm{C}$ for $20 \mathrm{~s}$ and final elongation at $72^{\circ} \mathrm{C}$ for $1 \mathrm{~min}$. A total of $28 \mathrm{PCR}$ cycles were run. PCR products were screened by gel electrophoresis before purification using Monarch ${ }^{\circledR}$ PCR and DNA purification kit (New England Biolabs, Germany). PCR products were quantified using Quant-iT PicoGreen dsDNA assay kit (Thermo Fisher Scientific, United States). Based on the measured quantities by PicoGreen, a library of samples was constructed using equimolar amounts from each amplicon. Amplicon library was sequenced at GATC GmbH (Konstanz, Germany) using the Illumina 2*150 base pairs HiSeq 4000 Platform.

\section{Sequence Analysis}

Sequence analysis was performed on the QIIME 1.8.0 platform (Caporaso et al., 2010) based on the 16S rRNA gene profiling analysis pipeline recommended by Pylro et al. (2014) with modifications. Forward reads were used as inputs for analysis from which barcodes were extracted followed by de-multiplexing with a Q20 filter quality (Caporaso et al., 2011). De-multiplexed sequences were further quality filtered with USEARCH 8.1 (Edgar, 2010). All sequences were truncated to a length of $143 \mathrm{bp}$. 
USEARCH 8.1 was further used to de-replicate sequences, sort them by their abundances and remove singletons. OTU clustering was done using the UPARSE-OTU algorithm (Edgar, 2013) to create an OTU database. Chimeric sequences were automatically discarded by the UPARSE-OTU algorithm during this step. The truncated, non-dereplicated reads were mapped back to the OTU database to create an OTU table. OTUs were classified for their taxonomy based on a 97\% identity threshold using UCLUST (Edgar, 2010) and SILVA database as reference. The final OTU table was used for taxonomic annotations in the downstream analysis of community composition. Bacteria sequence reads from archaea OTU table and Archaea sequence reads from Bacteria OTU table were removed after which absolute numbers of the remaining reads in the respective OTU tables were processed for microbial community analysis (Supplementary Tables S3, S4). For graphical representation, abundance data from the OTU table was scaled to the sum of observation in each sample. The raw sequence data for this study have been submitted to GenBank Short Reads Archive (SRA) under the accession number SRP123441.

\section{Statistical Analysis}

Significant influence of hematite and magnetite amendment to methane formation rates was inferred by performing post hoc analysis with Tukey procedures for each temperature and time point. The general linear hypothesis test for triplicates with default adjustments for multiple testing was applied (Hothorn et al., 2008) within the $\mathrm{R}$ environment ( $\mathrm{R}$ Core Team, 2018; R version 3.4.4).

\section{RESULTS}

\section{Microbial Iron Reduction and Methanogenesis}

Microbial iron reduction, tracked by increasing $\mathrm{Fe}^{2+}$ concentrations in the aqueous phase over incubation time, was evident across all temperatures (Figures 1A-C). At $4^{\circ} \mathrm{C}$, $\mathrm{Fe}^{2+}$ concentrations were considerably higher in magnetiteglucose amended (MG) and hematite-glucose amended (HG) incubations in comparison to the "glucose only" control (G). This implies that reduction of magnetite and hematite occurred, albeit more pronounced in the case of magnetite (Figure $1 \mathrm{~A}$ ). At $10^{\circ} \mathrm{C}$, iron reduction was more pronounced in $\mathrm{MG}$ incubations than in G and HG incubations (Figure 1B). Reduction of the crystalline iron oxides was not observed at $30^{\circ} \mathrm{C}$ as similar concentrations of $\mathrm{Fe}^{2+}$ were detected in G, MG and HG incubations (Figure 1C). In general, the potential for microbial iron reduction increased with decrease in temperature from 30 to $4^{\circ} \mathrm{C}$ (Figure 2). By comparing the maximum amounts of $\mathrm{Fe}^{2+}$ observed in each treatment (Figure 2), we could show that in the MG treatments at $4{ }^{\circ} \mathrm{C}, 2.5$-fold more $\mathrm{Fe}^{2+}$ were detected than at $30^{\circ} \mathrm{C}$. Similarly, hematite also stimulated 1.8 -fold more $\mathrm{Fe}^{2+}$ at $4^{\circ} \mathrm{C}$ compared to the same treatments at $30^{\circ} \mathrm{C}$. Although additional iron oxides were not added to the $\mathrm{G}$ treatments, 1.4-fold more $\mathrm{Fe}^{2+}$ was measured at $4^{\circ} \mathrm{C}$ compared to $30^{\circ} \mathrm{C}$.
As a measure for the occurrence of mDIET as implied in previous studies (see Lovley, 2017 and references therein), we followed methane formation in all incubations assuming that the presence of (semi)conductive iron minerals such as hematite and magnetite would facilitate more efficient electron transfer to methanogenic archaea. Methanogenesis occurred after $\mathrm{Fe}^{2+}$ concentrations in the aqueous phase leveled off across all temperatures (Figures 1D-F). Based on the amounts of $\mathrm{CH}_{4}$ measured in the headspace across all incubations and the expected stoichiometry from glucose fermentation assuming all $68 \mu$ moles electrons from glucose is turned over to $\mathrm{CH}_{4}$, methanogenesis was the dominant sink for electrons across all temperatures (Table 1). At $30^{\circ} \mathrm{C}$, onset of methanogenesis was observed after 23 days and continued until 47 days (Figure 1F). Methanogenesis started much later at $10^{\circ} \mathrm{C}$ (after 120 days) and continued until no further increase in $\mathrm{CH}_{4}$ amounts was detected after 216 days (Figure 1E). At $4^{\circ} \mathrm{C}$, onset of methanogenesis was not observed after the initial 200 days. However, we observed after 2 years ( $\sim 780$ days, Figure 1D) that methanogenesis was completed in HG incubations but continued in the MG and $G$ incubations (898 days). Methanogenesis rates were lower with decrease in temperature from 30 to $4^{\circ} \mathrm{C}$ (Figures 3A-C). Across all temperatures, hematite enhanced methanogenesis in HG incubations such that both the onset and the maximum rates of methane formation were reached faster compared to G incubations (Figures 3A-C). Magnetite, similarly to hematite also enhanced the onset and maximum rates of methanogenesis; however, this was only observed at $30^{\circ} \mathrm{C}$ (Figure $3 \mathrm{C}$ ). At $10^{\circ} \mathrm{C}$, the enhanced onset of methanogenesis with magnetite was observed in only two of three replicates (Figure 3B). At $4^{\circ} \mathrm{C}$, addition of magnetite did not enhance methanogenesis (Figure 3A). In summary, we found that hematite enhanced methanogenesis both in terms of acceleration and maximum process rates, whereas the magnetite only improved its acceleration (i.e., the time between process onset and reaching maximum process rates), compared to incubations without iron oxide amendments.

In order to assess the role of methanogenesis in electron flow through iron oxides, methanogenesis was specifically inhibited by adding BES $(15 \mathrm{mM})$ to incubations $\left(30^{\circ} \mathrm{C}\right)$. Based on the $\mathrm{Fe}^{2+}$ concentrations measured, there was no difference in the rates of iron reduction in the presence of hematite and magnetite when compared to the glucose + BES incubations (Supplementary Figure S2).

\section{Microbial Community Shifts at Varying Incubation Temperatures}

Microbial community composition in slurry incubations was analyzed in order to identify key microorganisms involved in glucose and iron oxide utilization. Because of the different temperature regimes applied, microbial activities were different, which is reflected in the different time intervals of sampling (see Supplementary Figures S3-S5). At $4^{\circ} \mathrm{C}$, the genera Photobacterium and Psychromonas were dominant and their relative abundance was highest after 21 days (ranging from 24 to $34 \%$, respectively; Figure 4). While sequences related 
A

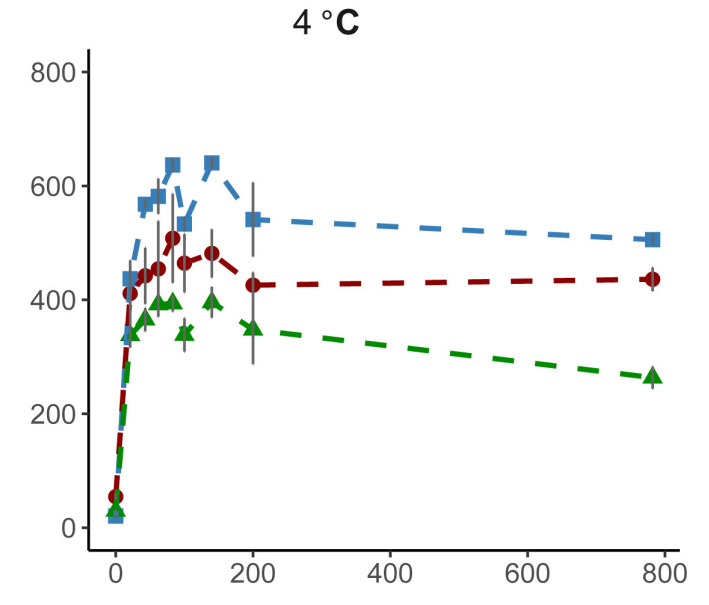

B

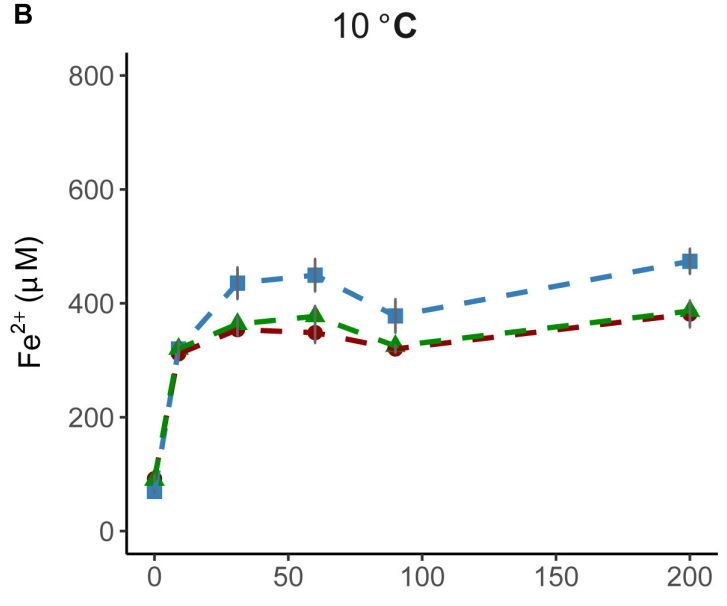

C

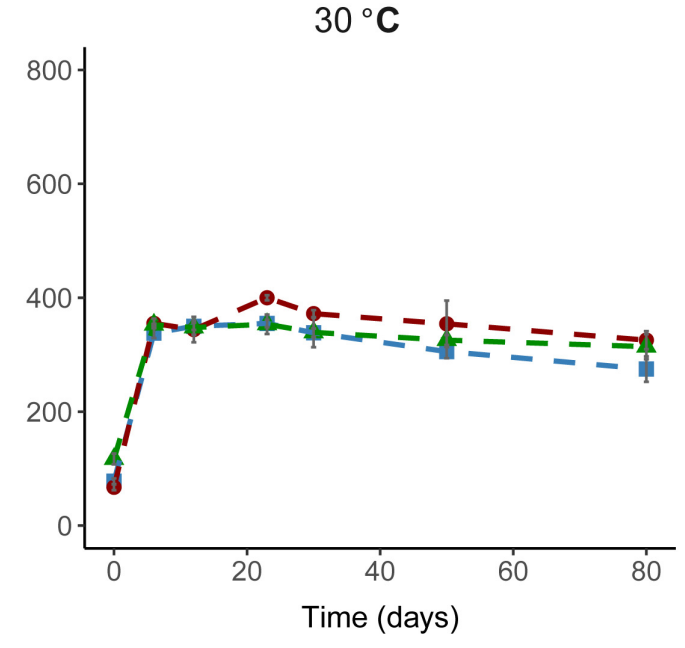

D

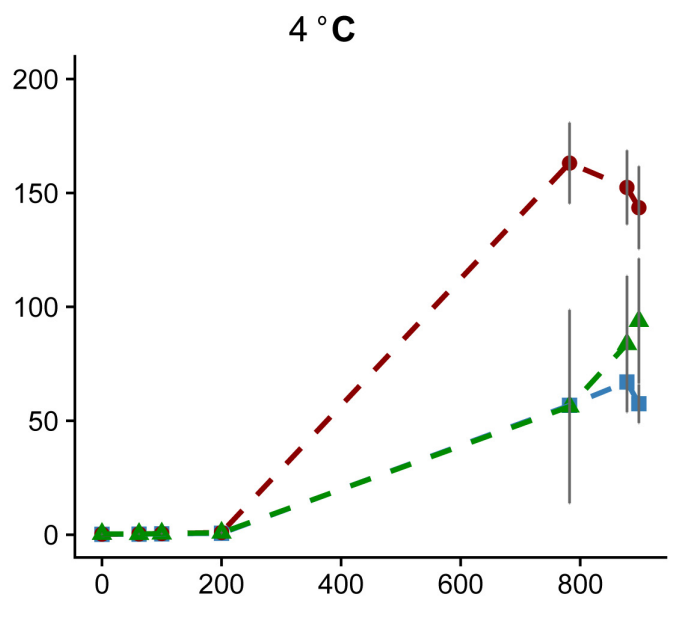

E

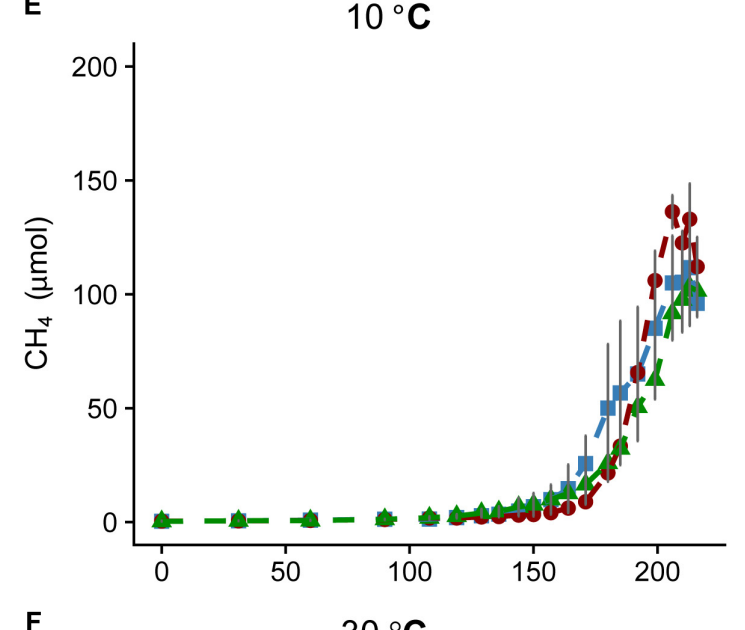

F

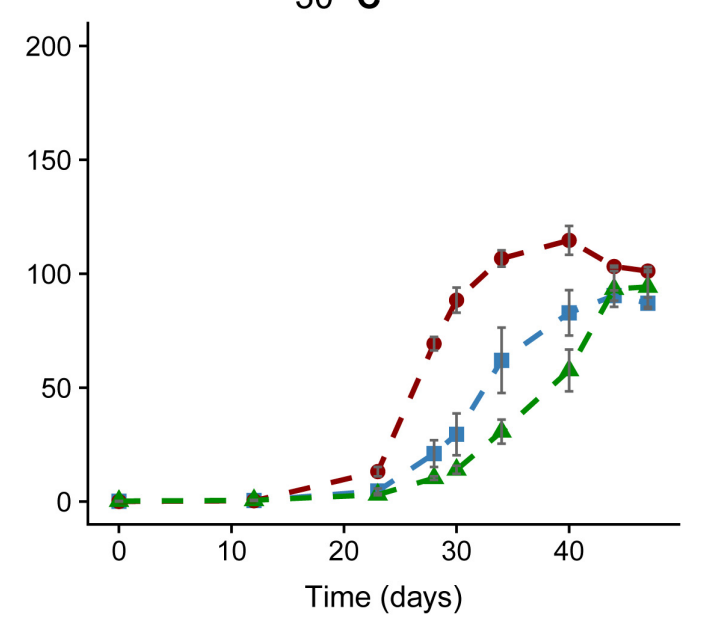

\section{Magnetite + Glucose $\rightarrow$ Hematite + Glucose $\rightarrow$ Glucose}

FIGURE 1 | Time course of iron reduction and methane formation in sediment incubations. Left column plots show time course of iron reduction at $4{ }^{\circ} \mathrm{C}(\mathbf{A}), 10^{\circ} \mathrm{C}$ (B), and $30^{\circ} \mathrm{C}$ (C). $\mathrm{Fe}^{2+}$ was measured over time until a stable concentration was observed in the aqueous phase across all temperatures. Right column plots show time course of methane formation at $4^{\circ} \mathrm{C}(\mathbf{D}), 10^{\circ} \mathrm{C}(\mathbf{E})$, and $30^{\circ} \mathrm{C}(\mathbf{F})$. In $(\mathbf{A})$, the 800 -day time point was added to demonstrate that iron reduction was not on-going in the methanogenesis phase. 


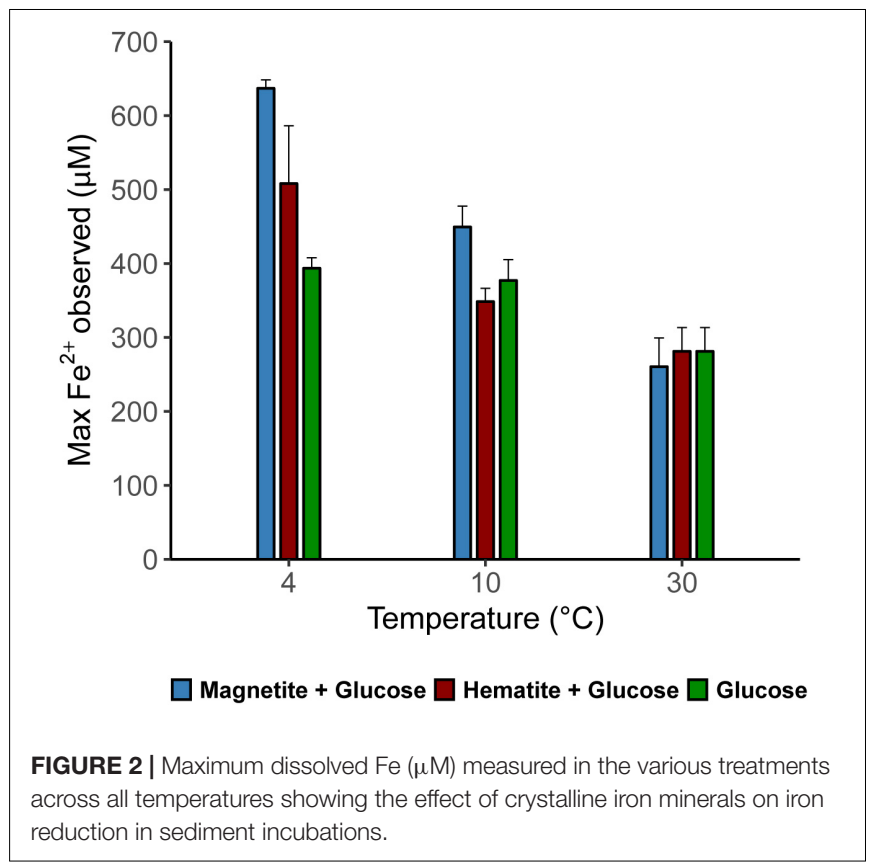

to Psychromonas were not observed at $10^{\circ} \mathrm{C}$, Photobacterium spp. were enriched (10-15\% after 90 days; Figure 4). Both Psychromonas and Photobacterium populations were absent at $30^{\circ} \mathrm{C}$; Figure 4. Members of the order Clostridiales were observed across all temperatures and were mostly dominant at $10^{\circ} \mathrm{C}$ (up to $36 \%$ at day 90). Within the order Clostridiales, the genus Fusibacter was observed across all temperatures (Supplementary Figure S7). However, there were differences in the other dominant Clostridiales family or genus observed at the different temperatures. For example, Alkalibacter spp. was low in relative abundance at $4^{\circ} \mathrm{C}(<1 \%)$; enriched at $10^{\circ} \mathrm{C}(3-6 \%$ after 90 days) in all treatments and was only observed in the magnetite amended treatment at $30^{\circ} \mathrm{C}(4 \%$, day 23). Family JTB 215 and Clostridiaceae_1 were only enriched at $30^{\circ} \mathrm{C}$ (Supplementary Figure S7). GoM-GC232-4463-Bac1 was enriched at $10^{\circ} \mathrm{C}$ and $30^{\circ} \mathrm{C}$ but not at $4^{\circ} \mathrm{C}$ (Supplementary Figure S7). Representatives of the order NB1-n (phylum Tenericutes) were present, but only at $10^{\circ} \mathrm{C}$ after 200 days (4-8\%; Figure 4$)$. At $30^{\circ} \mathrm{C}$, members of the genus Orenia were enriched (26-36\% after 23 days; Figure 4) but were not observed under psychrophilic conditions.

Known iron-reducing taxa detected in enrichments were related to the order Desulfuromonadales and the genus Sulfurospirillum (family Campylobacteraceae, class Epsilonproteobacteria) (Figure 5). At low temperatures, where we obtained indications that magnetite $\left(4^{\circ} \mathrm{C}\right.$ and $\left.10^{\circ} \mathrm{C}\right)$ and hematite $\left(4^{\circ} \mathrm{C}\right)$ reduction occurred, members of the order Desulfuromonadales were more abundant in MG and HG compared to the control, G (Figure 4). While Desulfuromonadales were also present at $30^{\circ} \mathrm{C}$, their relative abundance was lower in the iron oxide amendments (Figure 5). This correlated with the observations that hematite and magnetite were not reduced at $30^{\circ} \mathrm{C}$ (Figure 1). Within Desulfuromonadales, genus Desulfuromonas was the dominant taxa enriched at $4^{\circ} \mathrm{C}$ and $10^{\circ} \mathrm{C}$ (up to $11 \%$; Supplementary Figure S8). In contrast at $30^{\circ} \mathrm{C}$, the genus Pelobacter was dominant (up to 10\%; Supplementary Figure S8). The relative abundance of Pelobacter was less than $0.5 \%$ at $4^{\circ} \mathrm{C}$ and $10^{\circ} \mathrm{C}$ (Supplementary Figure S8). Desulfuromonas were only enriched in the magnetite amended treatment $(4.2 \pm 0.5 \%$ at day 50$)$ at $30^{\circ} \mathrm{C}$. At $4^{\circ} \mathrm{C}$, the relative abundance of members of the genus Sulfurospirillum in MG was higher after 83 days ( $9 \pm 1.8 \%$ ) compared to HG $(3 \pm 0.2 \%)$ and $\mathrm{G}(4.08 \pm 2 \%)$. Sulfurospirillum was not enriched at $10^{\circ} \mathrm{C}$ or $30^{\circ} \mathrm{C}$.

Among Archaea, Methanosarcina were the only methanogens enriched across all incubations regardless of incubation temperature (Figure 6). Generally, the relative abundance of other Archaea taxa did not change except at time-points when methanogenesis occurred and Methanosarcina was enriched (Supplementary Figures S3-S5).

\section{DISCUSSION}

\section{Crystalline Iron Oxides Utilization Under Temperature Control}

Iron oxide minerals are known as electron acceptors but their important role as conductors for facilitating microbial interspecies electron transfer was only recently recognized (Kato et al., 2012; Jiang et al., 2013; Cruz Viggi et al., 2014; Zhou et al., 2014). Conversely, factors are unknown that

TABLE 1 | Average amounts of methane formed and maximum methanogenesis rates per treatment across temperatures.

\begin{tabular}{|c|c|c|c|c|}
\hline Temperature & Treatment & $\begin{array}{c}\text { Average maximum } \mathrm{CH}_{4} \text { amount } \\
\text { measured }(\mu \mathrm{mol})\end{array}$ & $\begin{array}{l}\text { \% Expected } \mathrm{CH}_{4} \\
\text { accounted for }\end{array}$ & $\begin{array}{l}\text { Maximum } \mathrm{CH}_{4} \text { formation rate } \\
\left(\mathrm{nmol}^{*} \mathrm{ml} \mathrm{slurry}^{-1} \text { day }^{-1}\right)\end{array}$ \\
\hline \multirow[t]{3}{*}{$4^{\circ} \mathrm{C}$} & Glucose & $93.8 \pm 27.5$ & 46 & $1.9 \pm 1.5$ \\
\hline & Magnetite + Glucose & $67 \pm 5.8$ & 32.9 & $1.9 \pm 0.3$ \\
\hline & Hematite + Glucose & $163.1 \pm 17.8$ & 80 & $5.6 \pm 0.6$ \\
\hline \multirow[t]{3}{*}{$10^{\circ} \mathrm{C}$} & Glucose & $103.2 \pm 17$ & 50.6 & $83.5 \pm 22$ \\
\hline & Magnetite + Glucose & $111.7 \pm 16.3$ & 54.8 & $79 \pm 12.7$ \\
\hline & Hematite + Glucose & $136.3 \pm 7.2$ & 66.8 & $141.1 \pm 36$ \\
\hline \multirow[t]{3}{*}{$30^{\circ} \mathrm{C}$} & Glucose & $94.3 \pm 8.8$ & 46.2 & $179.2 \pm 38$ \\
\hline & Magnetite + Glucose & $90.4 \pm 2.2$ & 44.3 & $180 \pm 12.7$ \\
\hline & Hematite + Glucose & $114.7 \pm 6.3$ & 56.2 & $233.7 \pm 4.2$ \\
\hline
\end{tabular}




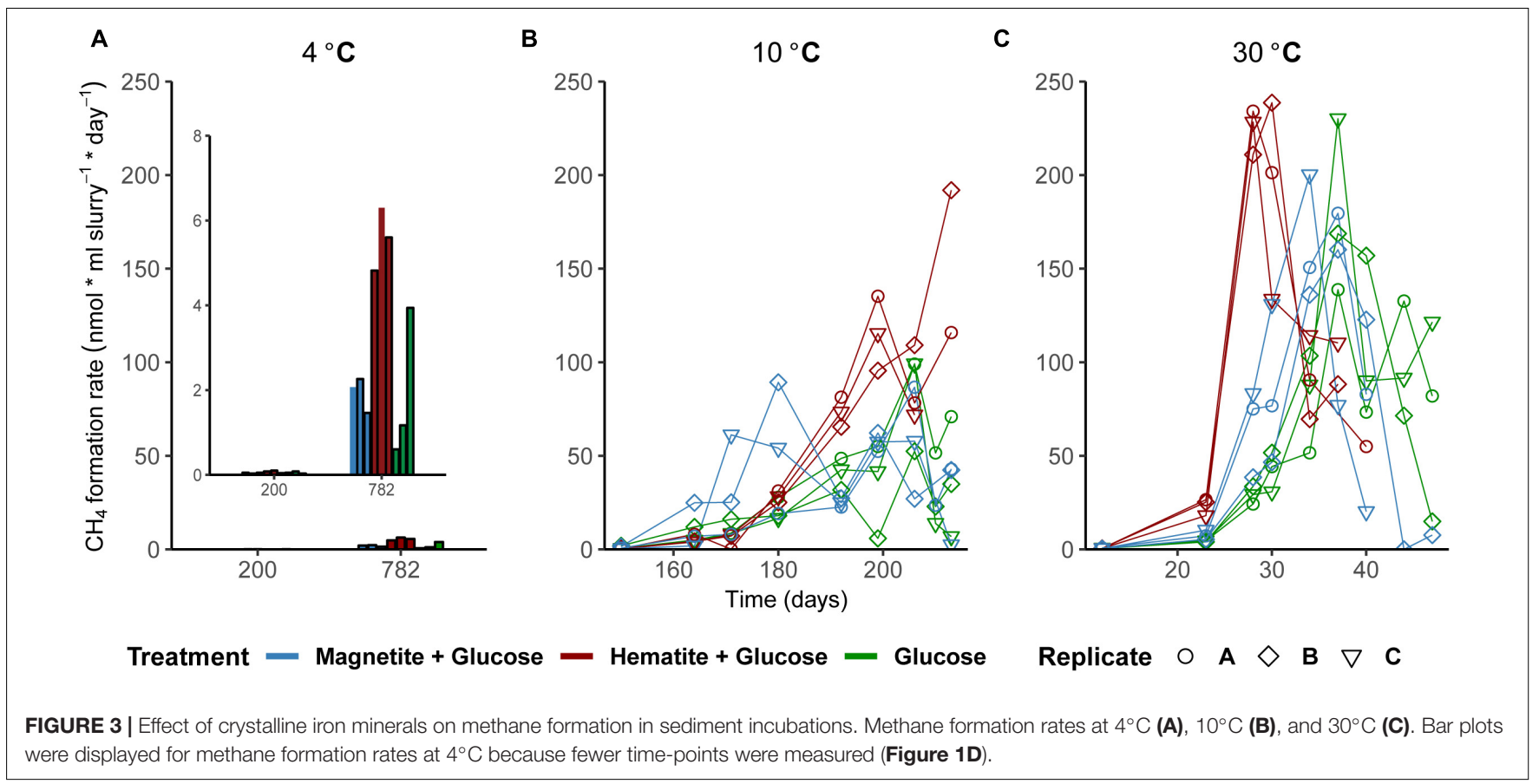

\section{$4{ }^{\circ} \mathrm{C}$}
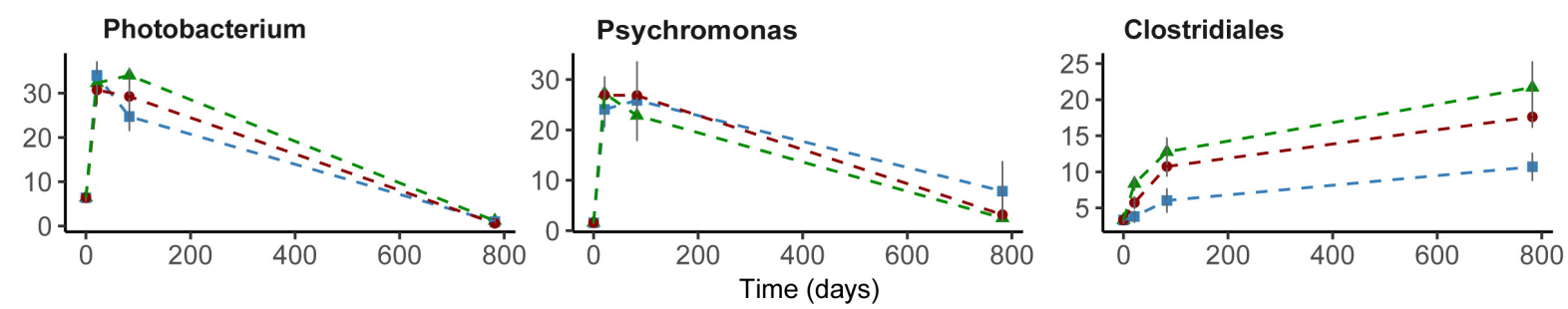

$10^{\circ} \mathrm{C}$
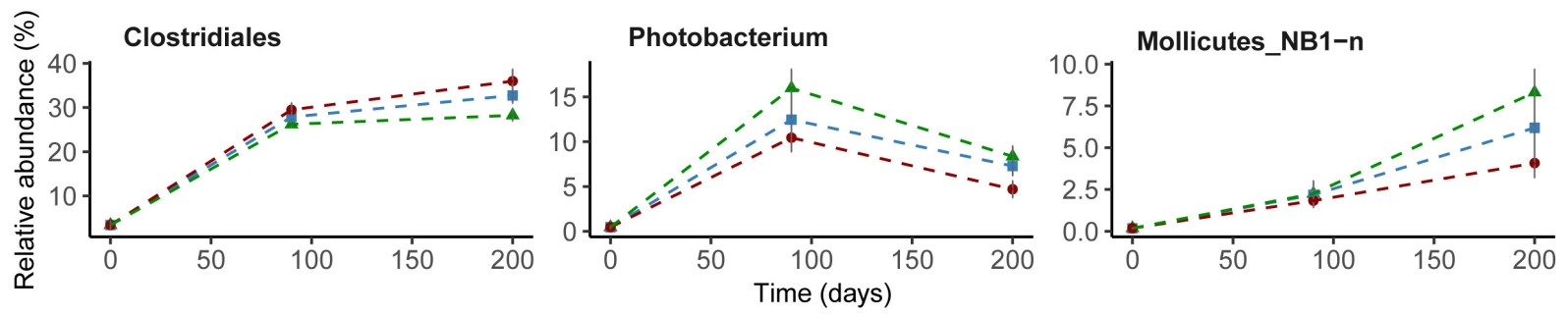

$30{ }^{\circ} \mathrm{C}$
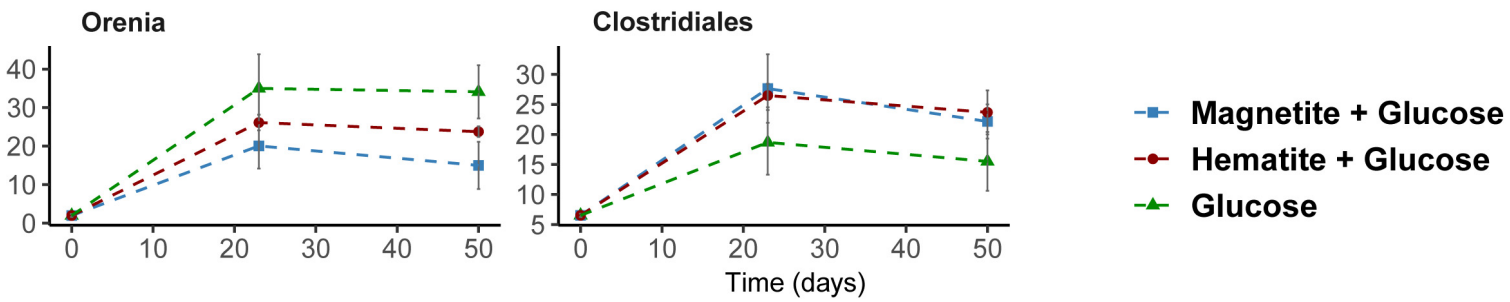

FIGURE 4 | Dominant bacteria communities enriched over time at $4^{\circ} \mathrm{C}, 10^{\circ} \mathrm{C}$, and $30^{\circ} \mathrm{C}$ determined by $16 \mathrm{~S}$ rRNA gene analysis. A threshold of relative abundance increase of $5 \%$ was used to determine key taxa (from order to genus level) compared to controls. Percentages show relative abundance of individual genus or order. Data presented here are reflecting the main bacteria taxa that were stimulated by glucose addition to slurry incubations. 

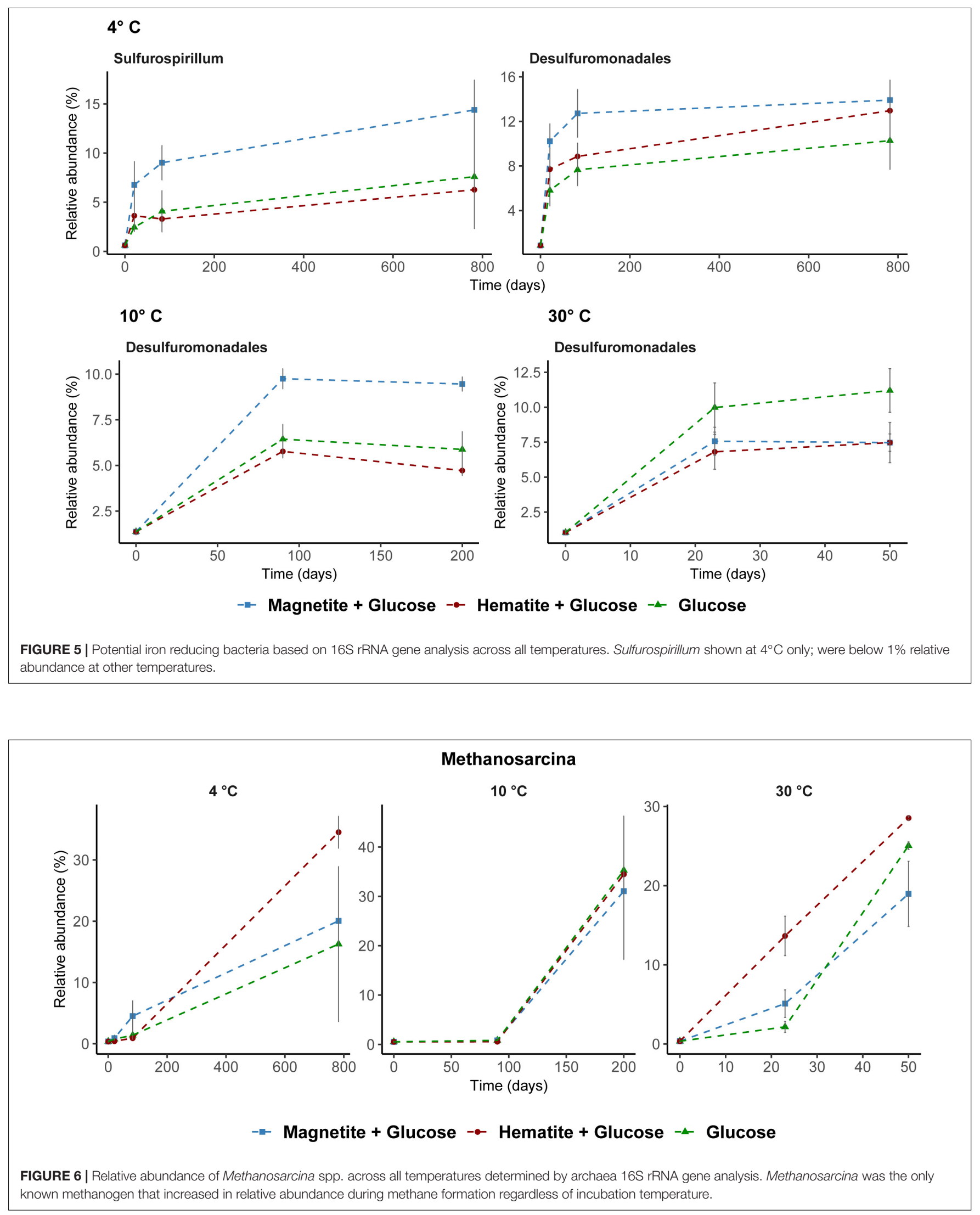
determine whether iron oxides are reduced in dissimilatory fashion or used to facilitate electron flow between microbial populations in the environment. Here, we demonstrate that temperature has a pronounced effect on crystalline iron oxide utilization in marine sediment incubations. A shift from low (i.e., $4-10^{\circ} \mathrm{C}$ ) to high temperature (i.e., $30^{\circ} \mathrm{C}$ ) resulted in lower iron reduction rates indicated by higher amounts of $\mathrm{Fe}^{2+}$ detected at lower temperatures (Figure 2). Consequently, electron transfer toward methanogenesis was enhanced in the presence of hematite or magnetite, especially at $30^{\circ} \mathrm{C}$ (Figures $3 \mathbf{A}-\mathbf{C}$ ). Thus, temperature appears to be a prime regulator controlling the mode (reduction or conduction) of iron oxide utilization by microorganisms in marine sediments. The underlying mechanisms are most likely multifactorial encompassing (1) community composition changes, (2) the reaction thermodynamics and pathways of degradation involved, and (3) specific adaptations to temperature.

Firstly, temperature is known to have a strong effect on metabolic adaptation and microbial community composition, both, for planktonic and benthic microorganisms (Fuhrman, 2009; Robador et al., 2009; Blake et al., 2015). Bottom water temperatures overlying the sediments of the Helgoland Mud Area are fluctuating annually between $2^{\circ} \mathrm{C}$ in March and $19^{\circ} \mathrm{C}$ in August (Oehler et al., 2015). Thus, incubations at $4^{\circ} \mathrm{C}$ and $10^{\circ} \mathrm{C}$ reflected seasonal in situ temperatures, whereas $30^{\circ} \mathrm{C}$ reflected a strong temperature shift. Not surprisingly, induced by different temperature regimes and glucose amendment, different key microorganisms were enriched (Supplementary Figures S3-S5) similar to other studies (Upton et al., 1990; Robador et al., 2009; Adams et al., 2010; Blake et al., 2015). In addition to their largely different taxonomic affiliations, temperature selected for communities that differed in their capabilities for crystalline iron oxide utilization (Figures 2, 3). Secondly, thermodynamics of the reactions involved seems to favor different physiological guilds competing for common electron donors. For example, methanogenesis is known to be thermodynamically more feasible under warmer (mesophilic) temperatures (Zeikus and Winfrey, 1976; Van Hulzen et al., 1999; Fey and Conrad, 2000; Yao and Conrad, 2000) than under lower temperatures (Conrad and Wetter, 1990), and can have a strong effect on carbon fractionation in temperature dependent methanogenesis (Fey et al., 2004). Nevertheless, methanogenic activity in freshwater and arctic wetland sediments has been observed over a wide temperature range from 1 to $45^{\circ} \mathrm{C}$ (Zeikus and Winfrey, 1976; Franzmann et al., 1992; Simankova et al., 2003; Blake et al., 2015). Some methanogenic isolates are psychrophiles. For example, Methanogenium frigidum, isolated from Ace Lake in Antarctica, which grows optimally at $15^{\circ} \mathrm{C}$ but not above $18-20^{\circ} \mathrm{C}$ (Franzmann et al., 1997). Sequences of methanogenic archaea were detected in sediments of the Helgoland Mud Area (Oni et al., 2015b) suggesting a potential for methanogenesis in these sediments. Although we did not observe methanogenesis at $4^{\circ} \mathrm{C}$ during the initial time-course of the experiments (200 days), its subsequent occurrence was only a matter of incubation time ( $\sim 780$ days). Methanosarcina were the only methanogens enriched from our incubations regardless of incubation temperature or addition of crystalline iron oxides (Figure 6) and majority of the electrons from glucose fermentation ended up being used by Methanosarcina for methane formation (Table 1). Microorganisms are known for specific temperature adaptations such as membrane fluidity, composition and expressed amount of enzymes, as well as specific regulation response for coping with temperature stress (D’Amico et al., 2006; De Maayer et al., 2014). Our results show that microbial iron reduction was more feasible at lower temperatures $\left(4^{\circ} \mathrm{C}\right.$ and $\left.10^{\circ} \mathrm{C}\right)$ than at $30^{\circ} \mathrm{C}$, to the extent that both amended crystalline iron minerals were reduced at $4^{\circ} \mathrm{C}$ (Figures 1A, 2). When methanogenesis was BES inhibited in $30^{\circ} \mathrm{C}$ incubations (Supplementary Figure S2), reduction of magnetite and hematite still remained low. Similar Bacteria communities were observed in the BES incubations when compared to the $30^{\circ} \mathrm{C}$ incubations without BES (Supplementary Figures S5, S6). Thus, the absence of enhanced iron reduction with magnetite or hematite addition at $30^{\circ} \mathrm{C}$ was not due to the onset and transfer of electrons from glucose fermentation to methanogenesis. Rather, the microorganisms enriched in the sediments at $4^{\circ} \mathrm{C}$ and $10^{\circ} \mathrm{C}$ are better adapted to perform crystalline iron oxide reduction than those enriched at $30^{\circ} \mathrm{C}$. Similarly, iron reduction rates increased with a decrease in temperature from 15 to $4^{\circ} \mathrm{C}$ in ferrihydrite reducing slurry incubations from glacial sediments (Nixon et al., 2017).

The observed strong increase in methanogenesis rates (up to twofold) in the presence of hematite (Figures 1, 3) suggests that (semi)conductive hematite may have served as conduit in our marine sediment incubations, facilitating mDIET. This is also the first study that demonstrates that mineral mediated enhancement of methanogenesis can occur at psychrophilic temperatures down to $4^{\circ} \mathrm{C}$. Therefore, mDIET based enhancement of methanogenesis, which has only been previously demonstrated in enrichments from rice field soils and river sediments (see Lovley, 2017); can also enhance methanogenesis in cold marine sediments. Electrons from glucose fermentation were likely shunted to methanogens via the (semi)conductive, crystalline iron minerals (i.e., hematite and magnetite). Similarly, Kato et al. (2012) found an enhancement of methane formation in rice field soil incubations, which was accompanied by stimulated growth of Geobacter spp. in incubations amended with hematite and magnetite. Comparable effects on methanogenesis were observed with magnetite at $30^{\circ} \mathrm{C}$, but at $10^{\circ} \mathrm{C}$ and $4^{\circ} \mathrm{C}$, magnetite served preferentially as an electron acceptor than as a conduit (Figures 1-3). At $4^{\circ} \mathrm{C}$, hematite apparently played a dual role, acting initially, as an electron acceptor and subsequently facilitating electron transfer when the conditions were favorable for methanogenesis to occur. More $\mathrm{Fe}^{2+}$ was observed in hematite + glucose incubations compared to the glucose amended control but methanogenesis was subsequently enhanced in hematite amended incubations (Figures 1A,D, 3A). Likewise, Zhou et al. (2014), in rice field soil enrichments incubated at $30^{\circ} \mathrm{C}$, observed a similar effect in the presence of magnetite.

Since sediment incubations are less defined than pure culture studies, other potential mechanisms could have been operative in addition to or instead of mDIET. Magnetite could have served 
as electron acceptor (Yang et al., 2015), or as part of an iron redox cycle, could have been important in the production of $\mathrm{H}_{2}$ from acetate to support hydrogenotrophic methanogenesis (Jiang et al., 2013); however, iron reduction was not observed in our incubations concurrently while methanogenesis was ongoing (Figure 1). More research is required to elucidate the exact mechanism for enhanced methanogenesis in the presence of crystalline iron oxides.

\section{Crystalline Iron Oxide Reducing Bacteria Under Psychrophilic Conditions}

Due to easier accessibility by microorganisms and thermodynamic favorability (Weber et al., 2006), poorly crystalline iron minerals have been mostly used in studying iron reduction in samples from sedimentary environments (Roden and Lovley, 1993; Zhang et al., 1999; Vandieken et al., 2006; Hori et al., 2015). This has led to the lack of knowledge of the diversity of microorganisms capable of reducing crystalline iron minerals, despite their abundance in natural environments (Hori et al., 2015).

The increase in the relative abundance of Sulfurospirillum with increasing concentration of $\mathrm{Fe}^{2+}$ (Figures 1A, 5) implies their involvement in dissimilatory reduction of magnetite at $4^{\circ} \mathrm{C}$. Members of the genus Sulfurospirillum have been previously linked to growth with poorly crystalline iron oxides at mesophilic temperatures. For example, Sulfurospirillum barnesii can use amorphous $\mathrm{Fe}$ (III) and ferrihydrite as terminal electron acceptors (Stolz et al., 1999; Zobrist et al., 2000) while S. deleyianum is capable of ferrihydrite dependent growth coupled to sulfur cycling (Straub and Schink, 2004; Lohmayer et al., 2014). The increase in relative abundance of Desulfuromonadales over time in the $4^{\circ} \mathrm{C}$ incubations correlated with the iron reduction kinetics, i.e., a higher relative abundance of Desulfuromonadales sequences was observed in incubations with higher $\mathrm{Fe}^{2+}$ concentration (Figures $1 \mathbf{A}, \mathbf{5}$ ). At $10^{\circ} \mathrm{C}$ in incubations with added magnetite, a higher abundance of Desulfuromonadales sequences also correlated with the higher $\mathrm{Fe}^{2+}$ concentrations measured (Figures 4, 1B). Along with the different temperature regimes, the dominant genus enriched within the Desulfuromonadales order were clearly different. Desulfuromonas was dominant at lower temperatures while Pelobacter was dominant at $30^{\circ} \mathrm{C}$ (Supplementary Figure S8). Desulfuromonas species are capable of reducing poorly crystalline iron oxides in marine surface sediments (Roden and Lovley, 1993; Vandieken et al., 2006). Here, we show they are involved in magnetite reduction as well under psychrophilic conditions in the marine sub-surface.

\section{mDIET-Linked Microorganisms Under Mesophilic and Psychrophilic Conditions}

Most known members of the family Halobacteroidaceae ferment carbohydrates to acetate, ethanol, $\mathrm{H}_{2}$, and $\mathrm{CO}_{2}$ (Oren, 2014). Besides, some species are homoacetogenic but can also use a variety of electron acceptors, e.g., selenate, arsenate, and iron oxides (Oren, 2014). Therefore, the dominance of the genus Orenia, regardless of the presence or absence of the crystalline iron oxides within the enriched communities at $30^{\circ} \mathrm{C}$ (Figure 4), suggests that members of the genus Orenia were largely responsible for glucose fermentation. In addition, Orenia might have been involved in iron reduction together with Pelobacter spp., who are capable of fermentative and dissimilatory Fe(III) reduction (Lovley et al., 1995). Syntrophic interactions that occur between microbes and iron minerals during methanogenic fermentation of organic matter mediate the electron transfer during these interactions (Kato et al., 2012; Yang et al., 2015). Although an isolated species within the genus, Orenia metallireducens strain Z6, can reduce both poorly crystalline and crystalline iron oxides (Dong et al., 2016), the reduction of amended magnetite and hematite was not detectable based on a lack of increasing $\mathrm{Fe}^{2+}$ concentrations at $30^{\circ} \mathrm{C}$. Thus, it is likely that the enriched members of the genus Orenia detected here shuttled electrons from glucose fermentation to Methanosarcina via mDIET to the amended hematite or magnetite; this in turn accelerated the onset of methane formation and enhanced the process rates (Figure 3C).

The enrichment of members of the known psychrophilic genera Photobacterium and Psychromonas at $4^{\circ} \mathrm{C}$ might be linked to glucose fermentation (Seo et al., 2005; Auman et al., 2006). Enrichment of different Clostridiales sub-groups at different temperatures (Supplementary Figure S7) demonstrates the versatility of the order Clostridiales to thrive at various temperature regimes. The order Clostridiales is well known for harboring a wide variety of fermenting microorganisms. For example, the genus Fusibacter which was enriched across all temperatures studied (Supplementary Figure S7) has been shown to be capable of glucose metabolism (Ravot et al., 1999; Hania et al., 2012; Fadhlaoui et al., 2015; Smii et al., 2015). Some organisms within the order Clostridiales are also exoelectrogens (Jiang et al., 2013; Fuller et al., 2014; Moscoviz et al., 2017), thus, they can potentially transfer electrons to methanogens directly via mDIET in our incubations. This in turn, may have resulted in the enhanced rates of methanogenesis observed at $10^{\circ} \mathrm{C}$ and $4^{\circ} \mathrm{C}$.

\section{CONCLUSION}

Our results open a new window into understanding environmental regulators of microbial interaction and utilization of crystalline iron minerals. We identified temperature as one of the regulators important for the mode of crystalline iron mineral utilization by microorganisms. We also demonstrate the potential for mDIET to occur in sub-surface marine sediments and at temperatures down to $4^{\circ} \mathrm{C}$. Thus, crystalline iron oxides may facilitate electron transfer between microorganisms thriving in anoxic cold sediments in addition to serving as electron acceptors. This extended role of crystalline iron oxides in microbial metabolism could have an impact on the biogeochemical cycling of carbon in sedimentary environments by accelerating the rate of organic carbon biomineralization. More work is certainly required to identify specific molecular adaptations to iron reduction or utilization as conduit under temperature control. 


\section{AUTHOR CONTRIBUTIONS}

DA, OO, TR-H, and MF designed the experiments. DA performed the experiments and data analysis with support from $\mathrm{OO}, \mathrm{AK}, \mathrm{XY}, \mathrm{TR}-\mathrm{H}$, and MF. MF secured funding for this research. SK carried out the HE433 expedition and provided sediment samples for the experiments. DA (90\%) and MF (10\%) wrote the manuscript with contributions from all co-authors.

\section{FUNDING}

This work was supported by the Deutsche Forschungsgemeinschaft (DFG) Cluster of Excellence 309 "The Ocean in the Earth System - MARUM - Center for Marine Environmental Sciences"

\section{REFERENCES}

Adams, H. E., Crump, B. C., and Kling, G. W. (2010). Temperature controls on aquatic bacterial production and community dynamics in arctic lakes and streams. Environ. Microbiol. 12, 1319-1333. doi: 10.1111/j.1462-2920.2010. 02176.x

Auman, A. J., Breezee, J. L., Gosink, J. J., Kampfer, P., and Staley, J. T. (2006). Psychromonas ingrahamii sp. nov., a novel gas vacuolate, psychrophilic bacterium isolated from Arctic polar sea ice. Int. J. Syst. Evol. Microbiol. 56(Pt 5), 1001-1007. doi: 10.1099/ijs.0.64068-0

Blake, L. I., Tveit, A., Øvreås, L., Head, I. M., and Gray, N. D. (2015). Response of methanogens in Arctic sediments to temperature and methanogenic substrate availability. PLoS One 10:e0129733. doi: 10.1371/journal.pone.0129733

Braunschweig, J., Bosch, J., and Meckenstock, R. U. (2013). Iron oxide nanoparticles in geomicrobiology: from biogeochemistry to bioremediation. New Biotechnol. 30, 793-802. doi: 10.1016/j.nbt.2013.03.008

Caporaso, J. G., Kuczynski, J., Stombaugh, J., Bittinger, K., Bushman, F. D., Costello, E. K., et al. (2010). QIIME allows analysis of high-throughput community sequencing data. Nat. Methods 7, 335-336. doi: 10.1038/nmeth.f. 303

Caporaso, J. G., Lauber, C. L., Walters, W. A., Berg-Lyons, D., Lozupone, C. A., Turnbaugh, P. J., et al. (2011). Global patterns of 16 S rRNA diversity at a depth of millions of sequences per sample. Proc. Natl. Acad. Sci. U.S.A. 108(Suppl. 1), 4516-4522. doi: 10.1073/pnas.1000080107

Conrad, R., and Wetter, B. (1990). Influence of temperature on energetics of hydrogen metabolism in homoacetogenic, methanogenic, and other anaerobic bacteria. Arch. Microbiol. 155, 94-98. doi: 10.1007/bf00291281

Cornell, R. M., and Schwertmann, U. (2003). The iron oxides: structure, properties, reactions, occurrences and uses, 2nd Edn. Hoboken, NJ: John Wiley \& Sons. doi: 10.1002/3527602097

Cruz Viggi, C., Rossetti, S., Fazi, S., Paiano, P., Majone, M., and Aulenta, F. (2014). Magnetite particles triggering a faster and more robust syntrophic pathway of methanogenic propionate degradation. Environ. Sci. Technol. 48, 7536-7543. doi: 10.1021/es5016789

D’Amico, S., Collins, T., Marx, J.-C., Feller, G., and Gerday, C. (2006). Psychrophilic microorganisms: challenges for life. EMBO Rep. 7, 385-389. doi: 10.1038/sj.embor.7400662

De Maayer, P., Anderson, D., Cary, C., and Cowan, D. A. (2014). Some like it cold: understanding the survival strategies of psychrophiles. EMBO Rep. 15, 508-517. doi: 10.1002/embr.201338170

Dong, Y., Sanford, R. A., Boyanov, M. I., Kemner, K. M., Flynn, T. M., O’Loughlin, E. J., et al. (2016). Orenia metallireducens sp. nov. strain Z6, a novel metalreducing member of the phylum Firmicutes from the deep subsurface. Appl. Environ. Microbiol. 82, 6440-6453. doi: 10.1128/aem.02382-16

Edgar, R. C. (2010). Search and clustering orders of magnitude faster than BLAST. Bioinformatics 26, 2460-2461. doi: 10.1093/bioinformatics/btq461

Edgar, R. C. (2013). UPARSE: highly accurate OTU sequences from microbial amplicon reads. Nat. Methods 10, 996-998. doi: 10.1038/nmeth.2604 the Alfred Wegener Institute Helmholtz Centre for Polar and Marine Research and the University of Bremen.

\section{ACKNOWLEDGMENTS}

The authors thank the captain, crew, and scientists of RV HEINCKE expedition 443 to the Helgoland Mud Area.

\section{SUPPLEMENTARY MATERIAL}

The Supplementary Material for this article can be found online at: https://www.frontiersin.org/articles/10.3389/fmicb. 2018.02574/full\#supplementary-material

Egger, M., Hagens, M., Sapart, C. J., Dijkstra, N., van Helmond, N. A., Mogollón, J. M., et al. (2017). Iron oxide reduction in methane-rich deep Baltic Sea sediments. Geochim. Cosmochim. Acta 207, 256-276. doi: 10.1016/j.gca.2017. 03.019

Fadhlaoui, K., Hania, W. B., Postec, A., Fauque, G., Hamdi, M., Ollivier, B., et al. (2015). Fusibacter fontis sp. nov., a sulfur-reducing, anaerobic bacterium isolated from a mesothermic Tunisian spring. Int. J. Syst. Evol. Microbiol. 65, 3501-3506. doi: 10.1099/ijsem.0.000445

Fey, A., Claus, P., and Conrad, R. (2004). Temporal change of 13C-isotope signatures and methanogenic pathways in rice field soil incubated anoxically at different temperatures. Geochim. Cosmochim. Acta 68, 293-306. doi: 10.1016/ S0016-7037(03)00426-5

Fey, A., and Conrad, R. (2000). Effect of temperature on carbon and electron flow and on the archaeal community in methanogenic rice field soil. Appl. Environ. Microbiol. 66, 4790-4797. doi: 10.1128/aem.66.11.4790-4797.2000

Franzmann, P. D., Liu, Y., Balkwill, D. L., Aldrich, H. C., Conway De Macario, E., and Boone, D. R. (1997). Methanogenium frigidum sp. nov., a psychrophilic, H2-using methanogen from Ace Lake, Antarctica. Int. J. Syst. Evol. Microbiol. 47, 1068-1072. doi: 10.1099/00207713-47-4-1068

Franzmann, P. D., Springer, N., Ludwig, W., Conway De Macario, E., and Rohde, M. (1992). A methanogenic archaeon from Ace Lake, Antarctica: Methanococcoides burtonii sp. nov. Syst. Appl. Microbiol. 15, 573-581. doi: 10.1016/S0723-2020(11)80117-7

Fuhrman, J. A. (2009). Microbial community structure and its functional implications. Nature 459, 193-199. doi: 10.1038/nature08058

Fuller, S. J., McMillan, D. G., Renz, M. B., Schmidt, M., Burke, I. T., and Stewart, D. I. (2014). Extracellular electron transport-mediated Fe (III) reduction by a community of alkaliphilic bacteria that use flavins as electron shuttles. Appl. Environ. Microbiol. 80, 128-137. doi: 10.1128/aem.02282-13

Hamady, M., Walker, J. J., Harris, J. K., Gold, N. J., and Knight, R. (2008). Error-correcting barcoded primers for pyrosequencing hundreds of samples in multiplex. Nat. Methods 5, 235-237. doi: 10.1038/nmeth.1184

Hania, W. B., Fraj, B., Postec, A., Fadhlaoui, K., Hamdi, M., Ollivier, B., et al. (2012). Fusibacter tunisiensis sp. nov., isolated from an anaerobic reactor used to treat olive-mill wastewater. Int. J. Syst. Evol. Microbiol. 62, 1365-1368. doi: 10.1099/ijs.0.034603-0

Hebbeln, D., Scheurle, C., and Lamy, F. (2003). Depositional history of the Helgoland mud area, German Bight, North Sea. Geomar. Lett. 23, 81-90. doi: 10.1007/s00367-003-0127-0

Hensen, C., Zabel, M., Pfeifer, K., Schwenk, T., Kasten, S., Riedinger, N., et al. (2003). Control of sulfate pore-water profiles by sedimentary events and the significance of anaerobic oxidation of methane for the burial of sulfur in marine sediments. Geochim. Cosmochim. Acta 67, 2631-2647. doi: 10.1016/S00167037(03)00199-6

Herlemann, D. P. R., Labrenz, M., Jurgens, K., Bertilsson, S., Waniek, J. J., and Andersson, A. F. (2011). Transitions in bacterial communities along the 2000 $\mathrm{km}$ salinity gradient of the Baltic Sea. ISME J. 5, 1571-1579. doi: 10.1038/ismej. 2011.41 
Hori, T., Aoyagi, T., Itoh, H., Narihiro, T., Oikawa, A., Suzuki, K., et al. (2015). Isolation of microorganisms involved in reduction of crystalline iron (III) oxides in natural environments. Front. Microbiol. 6:386. doi: 10.3389/fmicb. 2015.00386

Hothorn, T., Bretz, F., and Westfall, P. (2008). Simultaneous inference in general parametric models. Biomet. J. 50, 346-363. doi: 10.1002/bimj.200810425

Jiang, S., Park, S., Yoon, Y., Lee, J.-H., Wu, W.-M., Phuoc Dan, N., et al. (2013). Methanogenesis facilitated by geobiochemical iron cycle in a novel syntrophic methanogenic microbial community. Environ. Sci. Technol. 47, 10078-10084. doi: $10.1021 /$ es $402412 \mathrm{c}$

Kappler, A., and Straub, K. L. (2005). Geomicrobiological cycling of iron. Rev. Miner. Geochem. 59, 85-108. doi: 10.2138/rmg.2005.59.5

Kashefi, K., and Lovley, D. R. (2003). Extending the upper temperature limit for life. Science 301, 934-934. doi: 10.1126/science.1086823

Kashefi, K., Shelobolina, E. S., Elliott, W. C., and Lovley, D. R. (2008). Growth of thermophilic and hyperthermophilic Fe (III)-reducing microorganisms on a ferruginous smectite as the sole electron acceptor. Appl. Environ. Microbiol. 74, 251-258. doi: 10.1128/aem.01580-07

Kato, S., Hashimoto, K., and Watanabe, K. (2012). Methanogenesis facilitated by electric syntrophy via (semi) conductive iron-oxide minerals. Environ. Microbiol. 14, 1646-1654. doi: 10.1111/j.1462-2920.2011.02611.x

Lentini, C. J., Wankel, S. D., and Hansel, C. M. (2012). Enriched iron (III)reducing bacterial communities are shaped by carbon substrate and iron oxide mineralogy. Front. Microbiol. 3:404. doi: 10.3389/fmicb.2012.00404

Li, H., Chang, J., Liu, P., Fu, L., Ding, D., and Lu, Y. (2015). Direct interspecies electron transfer accelerates syntrophic oxidation of butyrate in paddy soil enrichments. Environ. Microbiol. 17, 1533-1547. doi: 10.1111/1462-2920.12576

Liu, F., Rotaru, A. E., Shrestha, P. M., Malvankar, N. S., Nevin, K. P., and Lovley, D. R. (2015). Magnetite compensates for the lack of a pilin-associated $c$-type cytochrome in extracellular electron exchange. Environ. Microbiol. 17, 648-655. doi: 10.1111/1462-2920.12485

Lohmayer, R., Kappler, A., Lösekann-Behrens, T., and Planer-Friedrich, B. (2014). Sulfur species as redox partners and electron shuttles for ferrihydrite reduction by Sulfurospirillum deleyianum. Appl. Environ. Microbiol. 80, 3141-3149. doi: 10.1128/aem.04220-13

Lovley, D. R. (1991). Dissimilatory Fe (III) and Mn (IV) reduction. Microbiol. Rev. $55,259-287$.

Lovley, D. R. (2017). Syntrophy goes electric: direct interspecies electron transfer. Annu. Rev. Microbiol. 71, 643-664. doi: 10.1146/annurev-micro-030117020420

Lovley, D. R., Phillips, E., Lonergan, D. J., and Widman, P. K. (1995). Fe(III) and S0 reduction by Pelobacter carbinolicus. Appl. Environ. Microbiol. 61, 2132-2138.

Lovley, D. R., and Phillips, E. J. (1986). Organic matter mineralization with reduction of ferric iron in anaerobic sediments. Appl. Environ. Microbiol. 51, 683-689.

Lovley, D. R., and Phillips, E. J. (1987). Rapid assay for microbially reducible ferric iron in aquatic sediments. Appl. Environ. Microbiol. 53, 1536-1540.

Lueders, T., Manefield, M., and Friedrich, M. W. (2004). Enhanced sensitivity of DNA-and rRNA-based stable isotope probing by fractionation and quantitative analysis of isopycnic centrifugation gradients. Environ. Microbiol. 6, 73-78. doi: 10.1046/j.1462-2920.2003.00536.x

Manzella, M. P., Reguera, G., and Kashefi, K. (2013). Extracellular electron transfer to Fe (III) oxides by the hyperthermophilic archaeon Geoglobus ahangari via a direct contact mechanism. Appl. Environ. Microbiol. 79, 4694-4700. doi: 10. 1128/aem.01566- 13

März, C., Hoffmann, J., Bleil, U., De Lange, G., and Kasten, S. (2008). Diagenetic changes of magnetic and geochemical signals by anaerobic methane oxidation in sediments of the Zambezi deep-sea fan (SW Indian Ocean). Mar. Geol. 255, 118-130. doi: 10.1016/j.margeo.2008.05.013

Moscoviz, R., de Fouchécour, F., Santa-Catalina, G., Bernet, N., and Trably, E. (2017). Cooperative growth of Geobacter sulfurreducens and Clostridium pasteurianum with subsequent metabolic shift in glycerol fermentation. Sci. Rep. 7:44334. doi: 10.1038/srep44334

Munch, J., and Ottow, J. (1983). Reductive transformation mechanism of ferric oxides in hydromorphic soils. Ecol. Bull. 35, 383-394.

Munch, J. C., and Ottow, J. C. G. (1980). Preferential reduction of amorphous to crystalline iron oxides by bacterial activity. Soil Sci. 129, 15-21. doi: 10.1097/ 00010694-198001000-00004
Nixon, S. L., Telling, J. P., Wadham, J. L., and Cockell, C. S. (2017). Viable coldtolerant iron-reducing microorganisms in geographically diverse subglacial environments. Biogeosciences 14, 1445-1455. doi: 10.5194/bg-14-14452017

Oehler, T., Schlüter, M., and Schückel, U. (2015). Seasonal dynamics of the biogenic silica cycle in surface sediments of the Helgoland Mud Area (Southern North Sea. Cont. Shelf Res. 107(Suppl. C), 103-114. doi: 10.1016/j.csr.2015. 07.016

Oni, O. E. (2015). Structure and Function of Microorganisms in the Methanic Sediments of the Helgoland Mud Area, North Sea, Germany. Ph.D. thesis, University of Bremen, Bremen.

Oni, O. E., Miyatake, T., Kasten, S., Richter-Heitmann, T., Fischer, D., Wagenknecht, L., et al. (2015a). Distinct microbial populations are tightly linked to the profile of dissolved iron in the methanic sediments of the Helgoland mud area, North Sea. Front. Microbiol. 6:365. doi: 10.3389/fmicb. 2015.00365

Oni, O. E., Schmidt, F., Miyatake, T., Kasten, S., Witt, M., Hinrichs, K.-U., et al. (2015b). Microbial communities and organic matter composition in surface and subsurface sediments of the Helgoland mud area, North Sea. Front. Microbiol. 6:1290. doi: 10.3389/fmicb.2015.01290

Oren, A. (2014). "The order Halanaerobiales, and the families Halanaerobiaceae and Halobacteroidaceae," in The Prokaryotes: Firmicutes and Tenericutes, eds E. Rosenberg, E. F. DeLong, S. Lory, E. Stackebrandt, and F. Thompson (Berlin: Springer), 153-177. doi: 10.1007/978-3-642-30120-9_218

Ovreås, L., Forney, L., Daae, F. L., and Torsvik, V. (1997). Distribution of bacterioplankton in meromictic Lake Saelenvannet, as determined by denaturing gradient gel electrophoresis of PCR-amplified gene fragments coding for 16S rRNA. Appl. Environ. Microbiol. 63, 3367-3373.

Parada, A. E., Needham, D. M., and Fuhrman, J. A. (2016). Every base matters: assessing small subunit rRNA primers for marine microbiomes with mock communities, time series and global field samples. Environ. Microbiol. 18, 1403-1414. doi: 10.1111/1462-2920.13023

Pylro, V. S., Roesch, L. F. W., Morais, D. K., Clark, I. M., Hirsch, P. R., and Tótola, M. R. (2014). Data analysis for 16S microbial profiling from different benchtop sequencing platforms. J. Microbiol. Meth. 107, 30-37. doi: 10.1016/j. mimet.2014.08.018

R Core Team (2018). R: A Language and Environment for Statistical Computing. Vienna: R Foundation for Statistical Computing.

Ravot, G., Magot, M., Fardeau, M.-L., Patel, B. K., Thomas, P., Garcia, J.-L., et al. (1999). Fusibacter paucivorans gen. nov., sp. nov., an anaerobic, thiosulfatereducing bacterium from an oil-producing well. Int. J. Syst. Evol. Microbiol. 49, 1141-1147. doi: 10.1099/00207713-49-3-1141

Riedinger, N., Formolo, M. J., Lyons, T. W., Henkel, S., Beck, A., and Kasten, S. (2014). An inorganic geochemical argument for coupled anaerobic oxidation of methane and iron reduction in marine sediments. Geobiology 12, 172-181. doi: $10.1111 /$ gbi.12077

Riedinger, N., Pfeifer, K., Kasten, S., Garming, J. F. L., Vogt, C., and Hensen, C. (2005). Diagenetic alteration of magnetic signals by anaerobic oxidation of methane related to a change in sedimentation rate. Geochim. Cosmoch. Acta 69, 4117-4126. doi: 10.1016/j.gca.2005.02.004

Robador, A., Brüchert, V., and Jørgensen, B. B. (2009). The impact of temperature change on the activity and community composition of sulfate-reducing bacteria in arctic versus temperate marine sediments. Environ. Microbiol. 11, 1692-1703. doi: 10.1111/j.1462-2920.2009.01896.x

Roden, E. E., and Lovley, D. R. (1993). Dissimilatory Fe (III) reduction by the marine microorganism Desulfuromonas acetoxidans. Appl. Environ. Microbiol. 59, 734-742.

Roden, E. E., and Zachara, J. M. (1996). Microbial reduction of crystalline iron (III) oxides: influence of oxide surface area and potential for cell growth. Environ. Sci. Technol. 30, 1618-1628. doi: 10.1021/es9506216

Roh, Y., Gao, H., Vali, H., Kennedy, D. W., Yang, Z. K., Gao, W., et al. (2006). Metal reduction and iron biomineralization by a psychrotolerant $\mathrm{Fe}$ (III)-reducing bacterium, Shewanella sp. strain PV-4. Appl. Environ. Microbiol. 72, 3236-3244. doi: 10.1128/aem.72.5.3236-3244.2006

Rotaru, A.-E., Calabrese, F., Stryhanyuk, H., Musat, F., Shrestha, P. M., Weber, H. S., et al. (2018). Conductive particles enable syntrophic acetate oxidation between Geobacter and Methanosarcina from coastal sediments. mBio 9:e00226-18. doi: 10.1128/mBio.00226-18 
Seo, H. J., Bae, S. S., Lee, J. H., and Kim, S. J. (2005). Photobacterium frigidiphilum sp. nov., a psychrophilic, lipolytic bacterium isolated from deep-sea sediments of Edison Seamount. Int. J. Syst. Evol. Microbiol. 55(Pt 4), 1661-1666. doi: 10.1099/ijs.0.63338-0

Shrestha, P. M., and Rotaru, A.-E. (2014). Plugging in or going wireless: strategies for interspecies electron transfer. Front. Microbiol. 5:237. doi: 10.3389/fmicb. 2014.00237

Simankova, M. V., Kotsyurbenko, O. R., Lueders, T., Nozhevnikova, A. N., Wagner, B., Conrad, R., et al. (2003). Isolation and characterization of new strains of methanogens from cold terrestrial habitats. Syst. Appl. Microbiol. 26, 312-318. doi: 10.1078/072320203322346173

Smii, L., Hania, W. B., Cayol, J.-L., Joseph, M., Hamdi, M., Ollivier, B., et al. (2015). Fusibacter bizertensis sp. nov., isolated from a corroded kerosene storage tank. Int. J. Syst. Evol. Microbiol. 65, 117-121. doi: 10.1099/ijs.0.066183-0

Stapleton, R. D. Jr., Sabree, Z. L., Palumbo, A. V., Moyer, C. L., Devol, A. H., Roh, Y., et al. (2005). Metal reduction at cold temperatures by Shewanella isolates from various marine environments. Aquat. Microb. Ecol. 38, 81-91. doi: 10.3354/ame038081

Stolz, J. F., Ellis, D. J., Blum, J. S., Ahmann, D., Lovley, D. R., and Oremland, R. S. (1999). Note: Sulfurospirillum barnesii sp. nov. and Sulfurospirillum arsenophilum sp. nov., new members of the Sulfurospirillum clade of the E-Proteobacteria. Int. J. Syst. Evol. Microbiol. 49, 1177-1180. doi: 10.1099/ 00207713-49-3-1177

Straub, K. L., Benz, M., and Schink, B. (2001). Iron metabolism in anoxic environments at near neutral pH. FEMS Microbiol. Ecol. 34, 181-186. doi: 10.1111/j.1574-6941.2001.tb00768.x

Straub, K. L., and Schink, B. (2004). Ferrihydrite-dependent growth of Sulfurospirillum deleyianum through electron transfer via sulfur cycling. Appl. Environ. Microbiol. 70, 5744-5749. doi: 10.1128/aem.70.10.5744-5749.2004

Takai, K., and Horikoshi, K. (2000). Rapid detection and quantification of members of the archaeal community by quantitative PCR using fluorogenic probes. Appl. Environ. Microbiol. 66, 5066-5072. doi: 10.1128/aem.66.11.50665072.2000

Upton, A. C., Nedwell, D. B., and Wynn-Williams, D. D. (1990). The selection of microbial communities by constant or fluctuating temperatures. FEMS Microbiol. Lett. 74, 243-252. doi: 10.1111/j.1574-6968.1990.tb04070

Van Hulzen, J., Segers, R., Van Bodegom, P., and Leffelaar, P. (1999). Temperature effects on soil methane production: an explanation for observed variability. Soil Biol. Biochem. 31, 1919-1929. doi: 10.1016/S0038-0717(99)00109-1

Vandieken, V., Mußmann, M., Niemann, H., and Jørgensen, B. B. (2006). Desulfuromonas svalbardensis sp. nov. and Desulfuromusa ferrireducens sp. nov., psychrophilic, Fe (III)-reducing bacteria isolated from Arctic sediments, Svalbard. Int. J. Syst. Evol. Microbiol. 56, 1133-1139. doi: 10.1099/ijs.0.63639-0
Viollier, E., Inglett, P., Hunter, K., Roychoudhury, A., and Van Cappellen, P. (2000). The ferrozine method revisited: Fe (II)/Fe (III) determination in natural waters. Appl. Geochem. 15, 785-790. doi: 10.1016/S0883-2927(99)00097-9

Weber, K. A., Achenbach, L. A., and Coates, J. D. (2006). Microorganisms pumping iron: anaerobic microbial iron oxidation and reduction. Nat. Rev. Microbiol. 4, 752-764. doi: 10.1038/nrmicro1490

Yang, Z., Shi, X., Wang, C., Wang, L., and Guo, R. (2015). Magnetite nanoparticles facilitate methane production from ethanol via acting as electron acceptors. Sci. Rep. 5:16118. doi: 10.1038/srep16118

Yao, H., and Conrad, R. (2000). Effect of temperature on reduction of iron and production of carbon dioxide and methane in anoxic wetland rice soils. Biol. Fert. Soils 32, 135-141. doi: 10.1007/s003740000

Zeikus, J., and Winfrey, M. (1976). Temperature limitation of methanogenesis in aquatic sediments. Appl. Environ. Microbiol. 31, 99-107.

Zhang, C., Stapleton, R. D., Zhou, J., Palumbo, A. V., and Phelps, T. J. (1999). Iron reduction by psychrotrophic enrichment cultures. FEMS Microbiol. Ecol. 30, 367-371. doi: 10.1111/j.1574-6941.1999.tb00664.x

Zhang, J., and Lu, Y. (2016). Conductive Fe3O4 nanoparticles accelerate syntrophic methane production from butyrate oxidation in two different lake sediments. Front. Microbiol. 7:1316. doi: 10.3389/fmicb.2016. 01316

Zhou, S., Xu, J., Yang, G., and Zhuang, L. (2014). Methanogenesis affected by the co-occurrence of iron (III) oxides and humic substances. FEMS Microbiol. Ecol. 88, 107-120. doi: 10.1111/1574-6941.12274

Zhuang, L., Tang, J., Wang, Y., Hu, M., and Zhou, S. (2015). Conductive iron oxide minerals accelerate syntrophic cooperation in methanogenic benzoate degradation. J. Hazard. Mater. 293, 37-45. doi: 10.1016/j.jhazmat.2015. 03.039

Zobrist, J., Dowdle, P. R., Davis, J. A., and Oremland, R. S. (2000). Mobilization of arsenite by dissimilatory reduction of adsorbed arsenate. Environ. Sci. Technol. 34, 4747-4753. doi: 10.1021/es001068h

Conflict of Interest Statement: The authors declare that the research was conducted in the absence of any commercial or financial relationships that could be construed as a potential conflict of interest.

Copyright (c) 2018 Aromokeye, Richter-Heitmann, Oni, Kulkarni, Yin, Kasten and Friedrich. This is an open-access article distributed under the terms of the Creative Commons Attribution License (CC BY). The use, distribution or reproduction in other forums is permitted, provided the original author(s) and the copyright owner(s) are credited and that the original publication in this journal is cited, in accordance with accepted academic practice. No use, distribution or reproduction is permitted which does not comply with these terms. 